Abstract-The picarel (Spicara smaris) is an interesting species of the Mediterranean Sea fishery, yet little information is available on life history of this protogynous species. A total of 6458 picarel (4.3 to 20.7 $\mathrm{cm}$ total length [TL]) were sampled from the Saronikos Gulf, an important fishing area in the eastern Mediterranean, during 1998 and 1999 to assess their age structure, sex-based growth, and sex-change pattern. Marginal-increment analysis combined with otolith edge analysis $(n=1694)$ showed that the time of annulus formation was around July (i.e., at the end of the spawning season). The length and age at sex change were estimated to be 15.3 cm TL and 3.0 years, respectively. The proportion of early maturing males, or males maturing before the length at sex change $\left(L_{50}\right)$, was $2.4 \%$, whereas the ratio of $L_{50}$ to maximum length was 0.74 , approximating the dimensionless theory. Males were shown to become longer than females, and the decreasing growth rate noticed between summer and autumn in fish older than 2 years, resulted in a strong oscillating growth pattern, clearly attributed to the synergistic effect of sex change and to large differences in summer and winter temperatures. Additionally, an alternative method for assigning fish to age groups, based on clusters derived from length distributions, is proposed.

Manuscript submitted 18 January 2018. Manuscript accepted 14 September 2018. Fish. Bull. 116:348-359 (2018).

Online publication date: 22 October 2018. doi: $10.7755 / F B .116 .3-4.12$

The views and opinions expressed or implied in this article are those of the author (or authors) and do not necessarily reflect the position of the National Marine Fisheries Service, NOAA.

\title{
Sex change and oscillating growth pattern of the picarel (Spicara smaris) in the Saronikos Gulf (Greece)
}

\author{
Constantina Karlou-Riga (retired) ${ }^{1}$ \\ Dimitra Petza (contact author)1,2,3 \\ Konstantinos Ganias ${ }^{4}$ \\ Email address for contact author: d.petza@marine.aegean.gr \\ 1 Fisheries Laboratory \\ Hellenic Ministry of Rural Development and Food \\ 15 Karaoli and Demetriou Street \\ Piraeus 18531, Greece \\ 2 Department of Marine Sciences \\ University of the Aegean \\ University Hill \\ Mytilene 81100, Greece \\ ${ }^{3}$ Directorate General for Fisheries \\ Hellenic Ministry of Rural Development and Food \\ 150 Syggrou Avenue \\ Athens 17671, Greece \\ ${ }^{4}$ School of Biology \\ Aristotle University of Thessaloniki \\ University Campus \\ Thessaloniki 54124, Greece
}

The picarel (Spicara smaris) is a very common species in the Mediterranean Sea and the Black Sea, but also occurs in the Sea of Marmara in Turkey and the southern part of the Sea of Azov, which connects Ukraine and Russia (Russell et al., 2015). Species of the genus Spicara occur in shallow rocky and muddy bottoms throughout the Mediterranean Sea and the Black Sea, in the Atlantic Ocean from Portugal to Morocco, and around the Canary Islands (Froese and Pauly ${ }^{1}$ ). These species contribute to inshore fisheries in Greece (Mytilineou and Papaconstantinou, 1991; Stergiou et al., 2011), and rep-

${ }^{1}$ Froese, R., and D. Pauly. 2018. Spicara smaris (Linnaeus, 1758): Picarel. FishBase. World Wide Web electronic publication. [Available from website.] resent a major proportion of the total catch for coastal fisheries in Croatia (Dulčiç et al., 2000). These species are also part of bycatch in the Mediterranean Sea but have low commercial value (Ragonese et al., 2004).

The picarel has been observed at depths from 15 to $170 \mathrm{~m}$ (Froese and Pauly $^{1}$ ) and down to $328 \mathrm{~m}$ in the eastern Ionian Sea (Mytilineou et al., 2005). This species has been used as a bio-indicator of the coastal and neritic environment (Wacquant and Lamare ${ }^{2}$ ).

In Greece, the picarel is rather popular as a food item and commer-

${ }^{2}$ Wacquant, C., and V. Lamare. 2014. Spicara smaris (Linnaeus, 1758). In Données d'Observations pour la Reconnaissance et l'Identification de la faune et la flore Subaquatiques (DORIS), 30/03/2014. [Available from website.] 


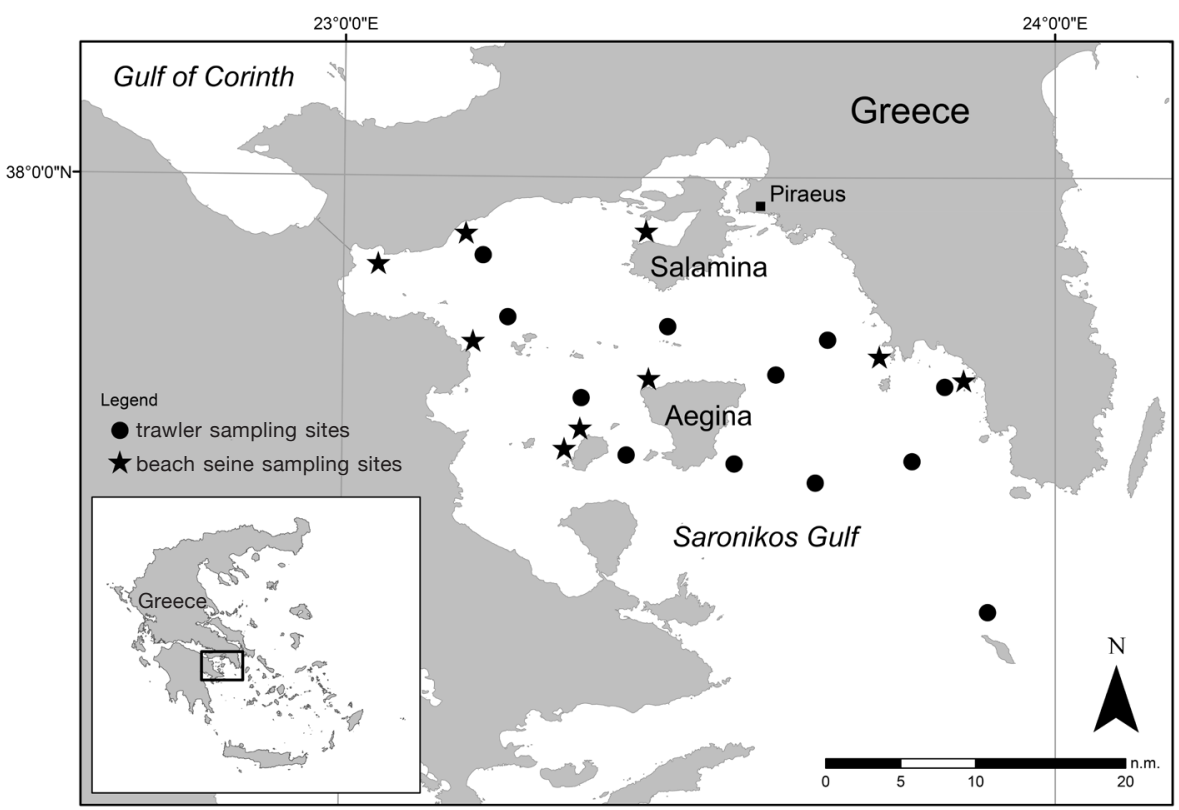

Figure 1

Map of the Saronikos Gulf in Greece showing sites where picarel (Spicara smaris) were sampled by trawler (black circles) or by beach seine (stars) from September 1998 through August 1999.

cially important. The ratio of picarel production to the total production for the period between 1990 and 2009 varied from 3.91 to 8.32 (sea fisheries statistics, National Statistical Service of Greece, available from website). It is caught by beach seines, trawlers, nets, and purse seines, but the catch by beach seines accounts for almost half of the catch by the other gears. Picarel represents the major target species of beach seine vessels; other congeneric species do not significantly contribute to the beach seine catch (Karlou-Riga et al., 1997; Papaconstantinou et al., 2007).

The picarel is a protogynous species and presents sexual dimorphism (Zei, 1950; Salekhova, 1979; Whitehead et al., 1986). Protogyny in picarel has also been confirmed histologically. During sexual transition, ovarian tissue degenerates and testicular tissue proliferates (Mitcheson and Liu, 2008). The fish occur in schools, except during time of breeding (Tsangridis and Filippousis, 1992). According to Harmelin and Harmelin-Vivien (1976), each nest is guarded by a brightly colored male. After incubation, the males lose their coloration and swim in schools to feeding areas. Regarding the age and growth of picarel in the Mediterranean Sea, the literature is quite extensive (Salekhova, 1979; Tsangridis and Filippousis, 1989, 1991, 1992; Ismen, 1995; Vidalis and Tsimenidis, 1996; Rizkalla, 1997; Dulčiç et al., 2003). Despite the number of publications, discrepancies do exist in both age determination and growth rates. It is noted, however, that Denaxa et al. (2014), who studied ages of picarel in Greek waters by means of otolith microstructure, gave important information on the first annulus formation.
Oscillating growth rates have been observed to influence sex change, but have never been studied in detail (Tsangridis and Filippousis, 1992). However, they have been recognized as the cause of discrepant length-atage estimates (Vidalis and Tsimenidis, 1996). Spawning seasonality and body sizes at sex change have, also, been identified as important in developing management plans for sustainable extraction of sequentially hermaphroditic species (DeMartini et al., 2011).

Here we attempt to validate ages or to use alternative ways to assign the specimen to age groups, as well as to address species growth on the basis of picarel sex change. Sex selection was also studied, and the presence of early maturing males (EMMs) was examined (Allsop and West, 2004a). Finally, the length and age at median (50\%) female-to-male sex change were investigated to see whether they are as invariant as predicted by Charnov and Skúladóttir (2000) and supported by Allsop and West (2003a). We consider the present work innovative, since both these alternative ways of age validation, as well as the growth study of a protogynous species examined within the sex change framework, are seldom found in the literature.

\section{Materials and methods}

Samples of picarel were collected monthly with a beach seine in the Saronikos Gulf (Fig. 1) during the period from September 1998 through August 1999 (Table 1). Because of bad weather conditions in November and December, a chartered bottom trawler was used in- 


\section{Table 1}

Data on sampling picarel (Spicara smaris) in the Saronikos Gulf off Greece from September 1998 through August 1999 with beach seine (SB) or otter bottom trawl (OTB).

\begin{tabular}{|c|c|c|c|c|}
\hline Sampling month & Fishing gear & $\begin{array}{l}\text { Number of } \\
\text { fish collected }\end{array}$ & $\begin{array}{l}\text { Number of } \\
\text { fish retained }{ }^{2}\end{array}$ & $\begin{array}{c}\text { Number of } \\
\text { otoliths removed }\end{array}$ \\
\hline September 1998 & SB & 681 & 213 & 137 \\
\hline October 1998 & SB & 969 & 278 & 152 \\
\hline November 1998 & OTB & 613 & 348 & 144 \\
\hline December 1998 & OTB & 278 & 176 & 129 \\
\hline January 1999 & SB & 1163 & 429 & 181 \\
\hline February 1999 & SB & 726 & 372 & 201 \\
\hline March 1999 & SB & 272 & 120 & 107 \\
\hline April 1999 & SB & 325 & 180 & 116 \\
\hline May 1999 & SB & 259 & 118 & 93 \\
\hline June 1999 & SB & 625 & 345 & 151 \\
\hline July 1999 & SB & 293 & 186 & 163 \\
\hline August 1999 & SB & 254 & 160 & 120 \\
\hline Total: & & 6458 & 2925 & 1694 \\
\hline
\end{tabular}

1 The number of fish collected for measurement of total length.

2 The number of fish retained in each 5 -cm length class each month.

stead. The mesh size of the codend of the beach seine and trawler net between stretched knots was 8 and $20 \mathrm{~mm}$, respectively. A total of 21 hauls were made in an effort to obtain as many representative samples as possible.

The unsorted picarel catch was placed in baskets on board. At the end of each haul, one basket was randomly selected and the total length (TL) of at least 200 individuals was measured to the nearest $0.5 \mathrm{~cm}$. Ten fish from each 0.5 -cm length class at each haul were retained. These fish were measured again for TL (to the nearest $0.1 \mathrm{~cm}$ ), weighed (W, to the nearest $1.0 \mathrm{~g}$ ) and sex was determined. After gross examination of the gonads, the fish were classified to maturity stages according to Nikolsky (1963). The number of specimens, by sex and maturity stage, was calculated on a monthly basis. From all the fish retained each month, both sagittae were removed from ten fish of each length class. However, only one (commonly the right sagitta) was thereafter analyzed. These otoliths were cleaned and kept dry.

The whole otoliths were examined while immersed in water under reflected light against a dark background, thus revealing alternating hyaline and opaque zones. The core of the otolith was opaque. Readings of hyaline zones (annuli) were made on the concave side and on both the posterior (postrostrum) and the anterior (rostrum) area of the otolith (Fig. 2). Development of the $1^{\text {st }}$ annulus was detected by following the progression of the smaller-fish length group and the structure of the respective otoliths in successive monthly samples (Campana, 2001).

The total otolith diameter and diameter of the annuli were measured along the posterior-anterior axis under a microscope by using a micrometer scale (Fig. 2). The growth increments, annuli, used for age determination, should be "validated" (Beamish and McFarlane, 1983). Among the different methods for validating absolute age or periodicity of growth increment formation, those of marginal increment (MI) and otolith edge analysis are suitable for validation (Campana, 2001). These increments, if formed on a yearly basis, are represented by a sinusoidal curve when plotted against time. In particular, MI is well suited for determining the time of annulus formation (Campana, 2001). In the present work, both the percentages of otoliths with a hyaline or opaque zone on the edge and the MIs were studied monthly. The MI was defined as the width outside the last completed annulus, irrespective of the type of edge (opaque or hyaline) (Karlou-Riga, 2000). Therefore, the time when the value of MI next to each annulus was highest corresponded with the period of the next annulus formation. Monthly mean values of MI were compared by using one-way analysis of variance.

The time of annulus formation, as well as the date of capture, the otolith edge (opaque or hyaline), and the spawning period were used to assign the fish to the appropriate age group (ICSEAF, 1986; Panfili et al., 2002). Each otolith was then characterized either by the $n^{\text {th }}$ incomplete annulus on the edge or the $n^{\text {th }}$ complete and opaque zone on the edge. Length distributions of specimens classified according to otolith readings were constructed. Based on similarity indices, these distributions were clustered for the period from January to June ( $1^{\text {st }}$ semester) and from July to December $\left(2^{\text {nd }}\right.$ semester $)$ separately. Whether the clusters derived corresponded with specimens of the same age groups, was then examined, according to age interpre- 


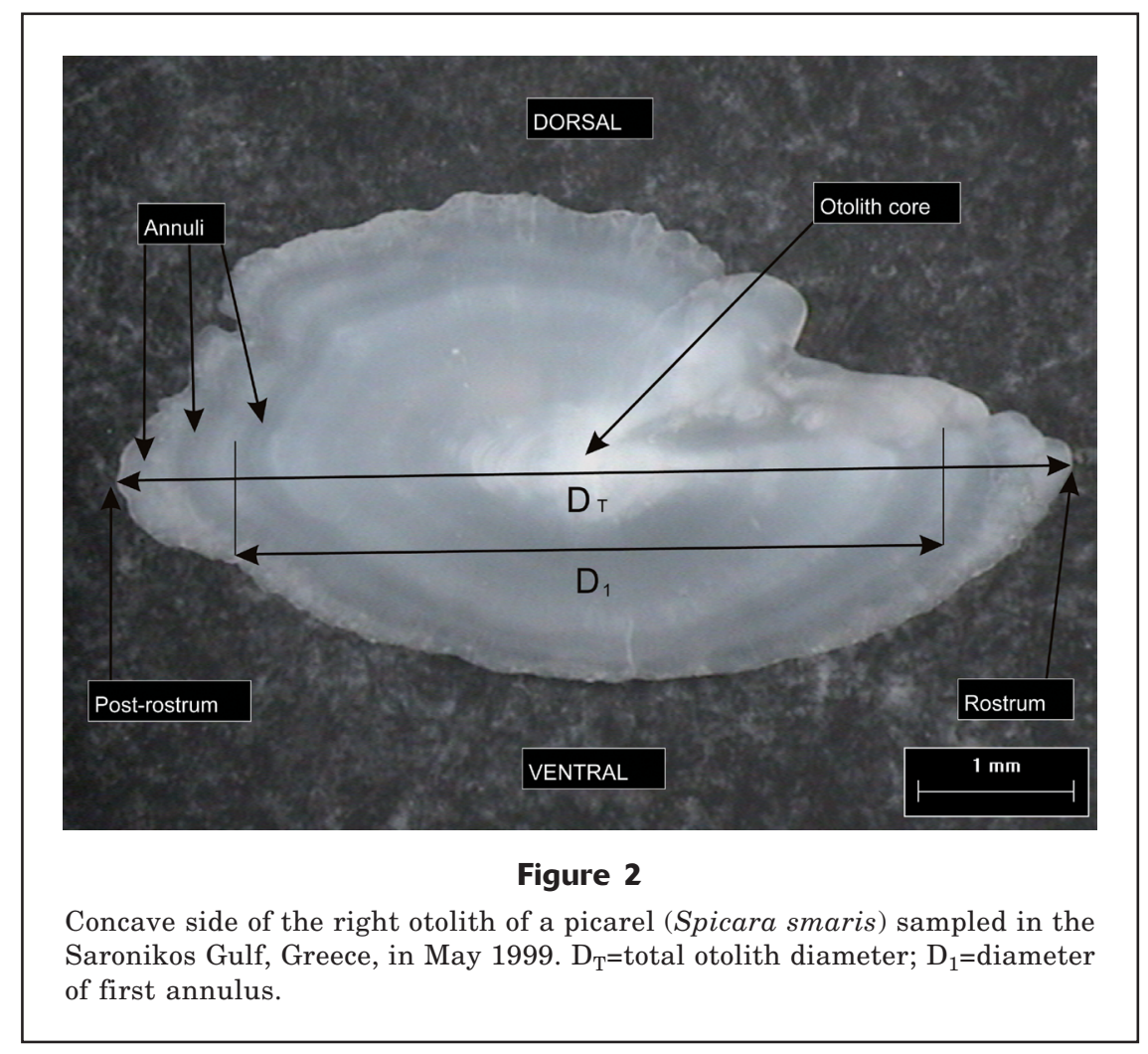

tation criteria. The Bray and Curtis (1957) similarity index was used and data were square-root transformed.

Growth parameters were estimated by the classic von Bertalanffy growth function (VBGF):

$$
L_{\mathrm{t}}=L_{\infty}\left(1-\mathrm{e}^{-K\left(t-t_{0}\right)}\right),
$$

where $L_{t}=$ TL at age $t$;

$L_{\infty}=$ the mean asymptotic TL;

$K=$ the growth coefficient; and

$t_{0}=$ the theoretical age at TL zero.

A total of three different runs of the classic VBGF were tested: one including all individuals (sex determined and sex undetermined), one run for the combination (total) of males and females and one run for each sex to investigate possible differences in growth patterns between male and female picarel. Model parameters were estimated by using the nonlinear least squares method fitted to the mean observed lengthsat-age (age in monthly units). In addition, the seasonal (oscillating) VBGF (Pauly and Gaschutz ${ }^{3}$ ) was also implemented in order to investigate a discontinuous growth pattern:

$$
L_{\mathrm{t}}=L_{\infty}\left\{1-\exp -\left[K\left(t-t_{0}\right)-\left(\left(\frac{C K}{2 \pi}\right) \sin \left(2 \pi\left(t-t_{S}\right)\right)\right]\right\},\right.
$$

where $C=$ the amplitude of the growth oscillation; and

${ }^{3}$ Pauly, D., and G. Gaschutz. 1979. A simple method for fitting oscillating length growth data, with a program for pocket calculators. ICES Council Meeting (C.M.) Documents 1979/G:24, 26 p. $t s=$ "summer point," the beginning of the sinusoid growth oscillation with respect to $t=0$ and corresponds with the time of year when growth rate is highest and is related to the winter point $(t w)$ by $t s+0.5=t w$.

In all cases residual diagnostic plots and histograms showed that models fitted the data appropriately. It should be noted that for many species from the Mediterranean Sea, the growth of young fish is very rapid (Caddy, 1989a, 1989b); therefore, the mean lengths-atage have to be expressed over time intervals of less than 1 year, as was done in the present study. This approach forces the growth curve close to the origin and provides a better data fit. Assuming 1 April as a conventional birthdate, we then expressed age in months.

According to Allsop and West (2003a), length and age at sex change is the length or age at which $50 \%$ of the population are the second sex (male for protogynous fish, female for protandrous fish), and estimates of this value are based on the proportion of the number of males in relation to the number of males and females either per length or per age. Dichotomous sex data (0:female; $1:$ male) were modeled as a function of TL and age by using generalized linear models (GLM) with a binomial error distribution and a logit link. The analysis led to estimates of length and age at median (50\%) female-to-male sex change $\left(L_{50}\right.$ and $A_{50}$, respectively). Standard errors for the $L_{50}$ and $A_{50}$ estimates were calculated by using the delta method. 


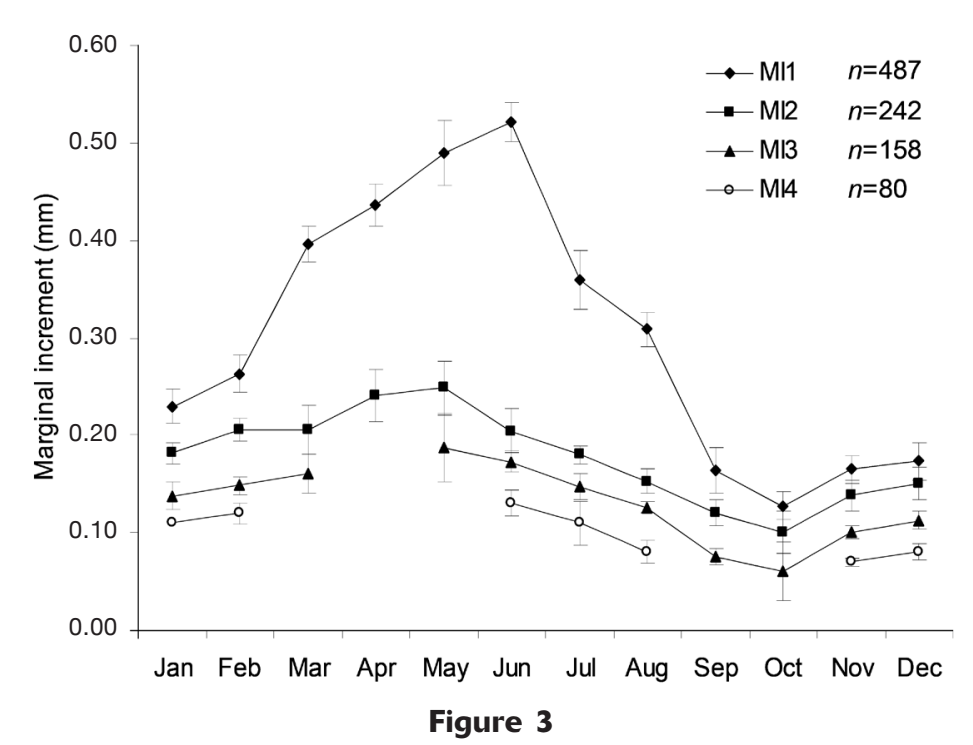

Monthly mean widths of otolith marginal increments next to the first (MI1), second (MI2), third (MI3), and fourth (MI4) annuli for picarel (Spicara smaris) collected during September 1998-August 1999 in the Saronikos Gulf, Greece. Bars indicate 2 standard errors of the mean.

Statgraphics Plus 5 software (Statgraphics Technologies, Inc., The Plains, VA). PRIMER 5 software (PRIMER-E, Auckland, New Zealand; Carr, 1997; Clarke and Gorley, 2001) was also used for obtaining the similarity index and for cluster analysis. All the statistical inferences were based on the 0.05-significance level.

\section{Results}

From a total of 6458 specimens collected, measuring 4.3 to $20.7 \mathrm{~cm}$ TL, $2925 \mathrm{fish}$ were retained for further measurements, from which 1694 otoliths were removed for age determination (Table 1 ). In the present study, the maximum length $\left(L_{\max }\right)$ of males and females was 20.7 and $19.7 \mathrm{~cm}$ TL, respectively. Specimens of undetermined sex ranged between 4.3 and $10.6 \mathrm{~cm}$ TL. Information on $L_{\max }$ values for picarel as drawn from the literature is given in the Supplementary Table.

Monthly length frequencies were constructed (Suppl. Fig. 1) to follow the progression of smaller fish modal lengths (4.5-

The presence of EMMs was examined in an effort to determine whether the species is diandrous and, if so, to estimate the relative proportion of fish maturing directly or early into males. According to Allsop and West (2004a), the proportion of EMMs is calculated by using the logistic parameters derived from the number of males in each length class at the $5^{\text {th }}$ percentile of the population length distribution according to the following equation:

$$
\text { Proportion male }(\text { sex ratio })=\frac{e^{(\mathrm{a}+\mathrm{bx})}}{1+e^{(\mathrm{a}+\mathrm{bx})}},
$$

where $a=$ the intercept of the logistic regression;

$b=$ the slope; and

$x=$ the length at the $5^{\text {th }}$ percentile.

According to Allsop and West (2004a), the sex ratio at the $5^{\text {th }}$ percentile is chosen because it is sufficiently close to the lower end of the population length distribution, to ensure that the males present are EMMs and not the product of sex change and so as to minimize the error inherent in measuring and determining the sex of these smaller-size individuals.

Classic and oscillated VBGF curves were fitted to the data by using a script in the fsa package, vers. 0.8.20 (Ogle, 2018) of statistical software R, vers. 3.4.2 ( $\mathrm{R}$ Core Team, 2017). Model diagnostics, including residual versus predicted plots and histograms were used for evaluating the goodness of fit of tested models. The linear correlation among study variables was examined by using the Pearson test. Additional statistical procedures were performed using
$8.0 \mathrm{~cm}$ TL) during the year, in order to examine annuli formation on the otoliths. The smaller specimens, which apparently belonged to the cohort of that year, were caught in July. The same cohort was followed in August, September, and October. The respective otoliths did not show any distinct hyaline zone (Suppl. Fig. 2A), which, however, started to be shown, with the progression of the same cohort, and in January samples. This hyaline margin increased progressively in successive months, and in some of the July otoliths, the hyaline zone, which was interpreted as the $1^{\text {st }}$ annulus, appeared complete (Suppl. Fig. 2B). The successive hyaline zones were interpreted as annuli mainly on the basis of the gradual decrease of their width and their formation at progressively greater distances from the core (Suppl. Fig. 2C). It seems that the $4^{\text {th }}$, the $5^{\text {th }}$, and the $6^{\text {th }}$ annuli appear very close to each other, and the contrast between the opaque and hyaline area is in general not strong. Despite this difficulty, the study of the otolith edge showed seasonality; the percentage of hyaline areas on the edge attained the highest value in June and the lowest in October (Suppl. Fig. 3). The oldest fish were found to have 6 annuli.

The MI widths next to the $1^{\text {st }}(\mathrm{MI} 1)$, the $2^{\text {nd }}$ (MI2), the $3^{\text {rd }}$ (MI3), and the $4^{\text {th }}$ (MI4) annuli showed a seasonal progression (one-way analysis of variance, $P<0.05, \mathrm{MI}$ : $\mathrm{df}=486, \mathrm{MI} 2: \mathrm{df}=241, \mathrm{MI}$ : $\mathrm{df}=157, \mathrm{MI}$ : $\mathrm{df}=79$ ). The lowest values of MIs were found in October and the highest values during May-June, indicating that the annuli are completed between June and October (Fig. 3). 
Table 2

Growth parameters of picarel (Spicara smaris) calculated by the different runs (classic, sex specific, and seasonal) of a von Bertalanffy growth function (VBGF) model for different subsets of individuals (all, males, and females): $L_{\infty}=$ the mean asymptotic total length; $K=$ the growth coefficient; $C=$ the amplitude of the growth oscillation; and $t$ s or summer point=the beginning of the sinusoid growth oscillation with respect to $t=0$. Standard errors are given in parentheses. MSE $=$ mean squared error; $n=$ number of specimens in each subset. Lengths are total lengths.

\begin{tabular}{|c|c|c|c|c|c|c|c|c|}
\hline VBGF & Data subset & $L_{\infty}(\mathrm{cm})$ & $K$ & $t_{0}$ (year) & $C$ & $t_{\mathrm{s}}$ & MSE & $n$ \\
\hline Classic & $\begin{array}{l}\text { All fish } \\
\text { Males and females }\end{array}$ & $\begin{array}{l}19.91(0.480) \\
19.93(0.697)\end{array}$ & $\begin{array}{l}0.512(0.059) \\
0.433(0.072)\end{array}$ & $\begin{array}{l}-0.412(0.145) \\
-0.843(0.265)\end{array}$ & & & $\begin{array}{l}0.015 \\
0.011\end{array}$ & 1694 \\
\hline Sex specific & $\begin{array}{l}\text { Females } \\
\text { Males }\end{array}$ & $\begin{array}{l}16.52(0.339) \\
20.29(0.656)\end{array}$ & $\begin{array}{l}0.973(0.158) \\
0.455(0.079)\end{array}$ & $\begin{array}{l}-0.040(0.163) \\
-0.745(0.288)\end{array}$ & & & 0.009 & $\begin{array}{l}951 \\
563\end{array}$ \\
\hline Seasonal & $\begin{array}{l}\text { Females } \\
\text { Males }\end{array}$ & $\begin{array}{l}16.95(0.461) \\
20.94(0.844)\end{array}$ & $\begin{array}{l}0.757(0.142) \\
0.379(0.072)\end{array}$ & $\begin{array}{l}-0.312(0.251) \\
-0.701(0.179)\end{array}$ & $\begin{array}{l}1.261(0.569) \\
1.261(0.569)\end{array}$ & $\begin{array}{l}-0.457(0.052) \\
-0.572(0.074)\end{array}$ & 0.018 & $\begin{array}{l}951 \\
563\end{array}$ \\
\hline
\end{tabular}

\section{Age interpretation criteria}

Because the picarel spawning period lasts from February to June (Suppl. Fig. 4), the fish spawned during this period constituted one cohort. Given that the annuli are completed in the $2^{\text {nd }}$ semester, specimens caught in the $1^{\text {st }}$ semester with $n$ annuli and an opaque zone on their otolith edge were assigned to the $n+1$ age group, whereas specimens with the $n^{\text {th }}$ annulus on the otolith edge caught either in the $1^{\text {st }}$ semester or the $2^{\text {nd }}$ semester, were assigned to the $n^{\text {th }}$ age group.

The following otolith readings were the most frequent: $\mathrm{OP}, \mathrm{H} 1, \mathrm{H} 1+\mathrm{OP}, \mathrm{H} 2, \mathrm{H} 2+\mathrm{OP}, \mathrm{H} 3, \mathrm{H} 3+\mathrm{OP}, \mathrm{H} 4$ and $\mathrm{H} 4+\mathrm{OP}$, where $\mathrm{OP}$ and $\mathrm{H}$ correspond to opaque and hyaline edges respectively, and the number specifies the successive annulus. The clusters of the length distributions, classified according to their otolith readings, are shown in Figure 4. It was observed that the clusters corresponded with specimens of those age groups obtained according to age interpretation criteria.

\section{Growth}

The mean lengths at age showed a significant difference between sexes ( $t$-test, $n=39, P<0.05$ ). Table 2 summarizes the VBGF parameters for the three versions of the model (classic, sex specific, and seasonal) and the various subsets investigated (all specimens and only specimens with identified sex). The growth curve that best fitted the data was the sex-specific VBGF (mean squared error $[\mathrm{MSE}]=0.009$, see Table 2). Based on this curve, asymptotic length for females and males was 16.52 and $20.29 \mathrm{~cm}$ TL respectively (Fig. 5A). The two runs of the classic VBGF for all fish (Fig. 5B) and for only fish with identified sex gave similar estimates of $L_{\infty}$ (all fish: $19.91 \mathrm{~cm}$ TL; for those with identified sex: $19.93 \mathrm{~cm} \mathrm{TL}$ ), similar $K$ values (all fish: 0.512; for those with identified sex: 0.433 ) and quite different $t_{0}$ values (all fish: -0.412 ; for those with identified sex: -0.843). Residual diagnostic plots and histograms are

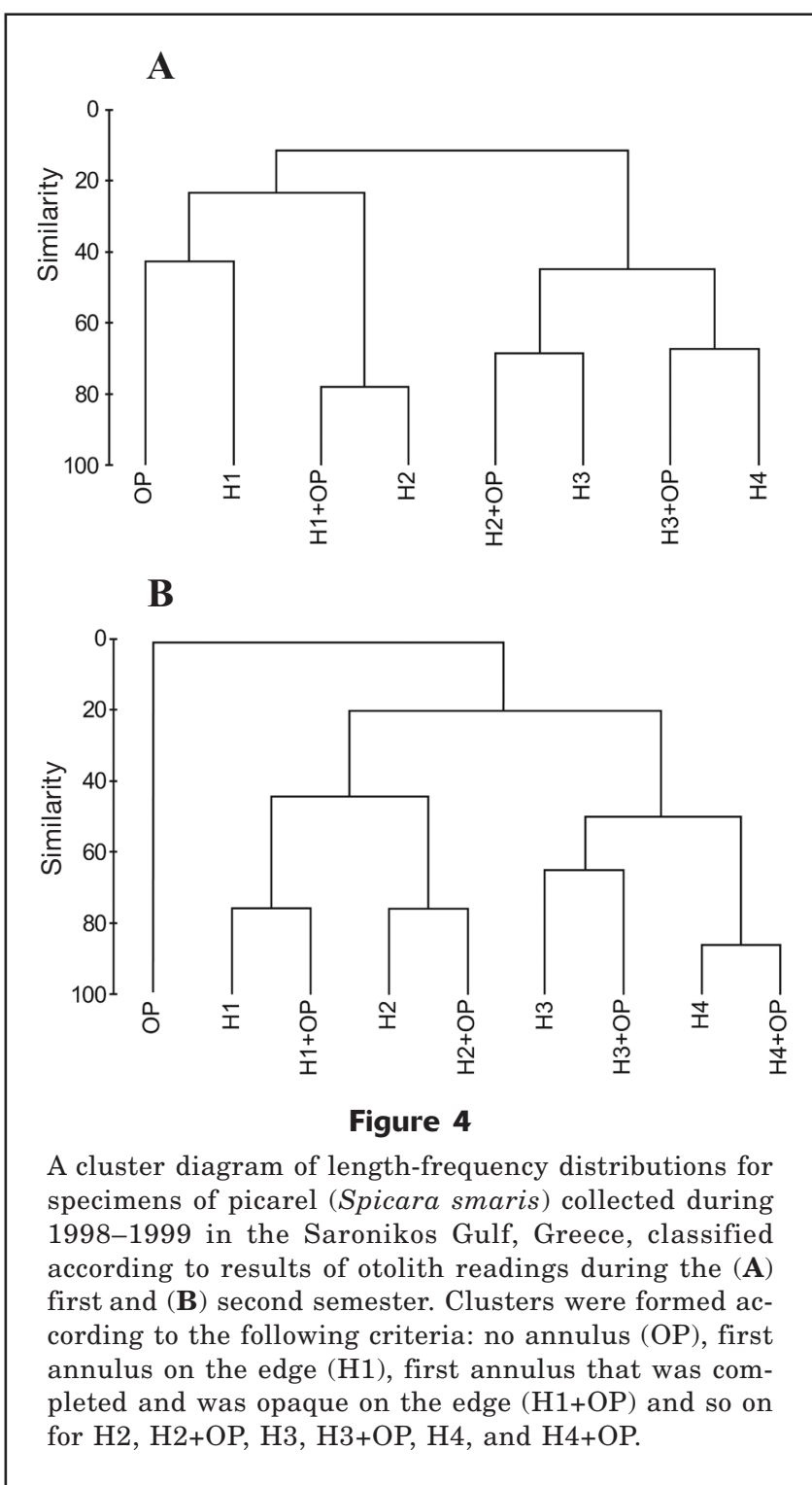


shown in Suppl. Fig. 5. The seasonal (oscillating) VBGF curve (Fig. 6) was also shown to fit data well (MSE=0.018), where the asymptotic length $\left(L_{\infty}=20.94 \mathrm{~cm} \mathrm{TL}\right)$, was found very close to the $L_{\max }(20.7 \mathrm{~cm}$ TL). It is worth noting the high value of the $C$ parameter (1.261), which clearly suggests a strong oscillating growth pattern with a prolonged no growth phase or a sustained period of no growth (Pauly and Gaschutz ${ }^{3}$ ).

In order to identify the season when change in growth occurs, or to examine the probable effect of sex change on the growth rate (Tsangridis and Filippousis, 1992; Vidalis and Tsimenidis, 1996), the observed mean lengths at age for each sex of picarel sampled were estimated during the life of the fish (Suppl. Fig. 6).

Examining the growth rate, it appears that males exhibit a higher growth rate than females, and a strong oscillating growth pattern is noticed during the $2^{\text {nd }}$, the $3^{\text {rd }}$, and the $4^{\text {th }}$ year of life. More specifically, a decrease of the average length for each sex is marked from summer to autumn. During the life of the species, the difference in length between males and females was found to be positively correlated with age (Pearson test: $n=34, P<0.05$ ).

\section{Length and age at sex change and proportion of early maturing males}

The proportion of males was found to be positively correlated with length (Pearson test: $n=34, P<0.05$ ) and with age (Pearson test: $n=57, P<0.05$ ), whereas the inverse occurred with the proportion of females. The coefficients of the binomial sex change model were $a=-10.105(P<0.01), b=0.654(P<0.01)$ and the $L_{50}$ was estimated as: $L_{50}=15.34 \mathrm{~cm}$ TL (CI=15.17-15.51) (Fig. 7A). The length at sex change divided by the $L_{\max }$ of the individuals, was 0.74. Respectively, the coefficients obtained from the number of males in each length class were $a=-4.711(P<0.01), b=0.135(P<0.01)$, and the $A_{50}$ was 36.4 months (CI=35.21-37.63 months) or 3.0 years (Fig. 7B).

Using the logistic parameters obtained from the number of males in each length class at the $5^{\text {th }}$ percentile of the population length distribution, we estimated the proportion of EMMs at $2.4 \%$.

\section{Discussion}

Despite the weak contrast between the opaque and hyaline zones particularly after the $3^{\text {rd }}$ annulus, the annuli of picarel were easily readable and show a normal growth pattern. The use of monthly samples during the
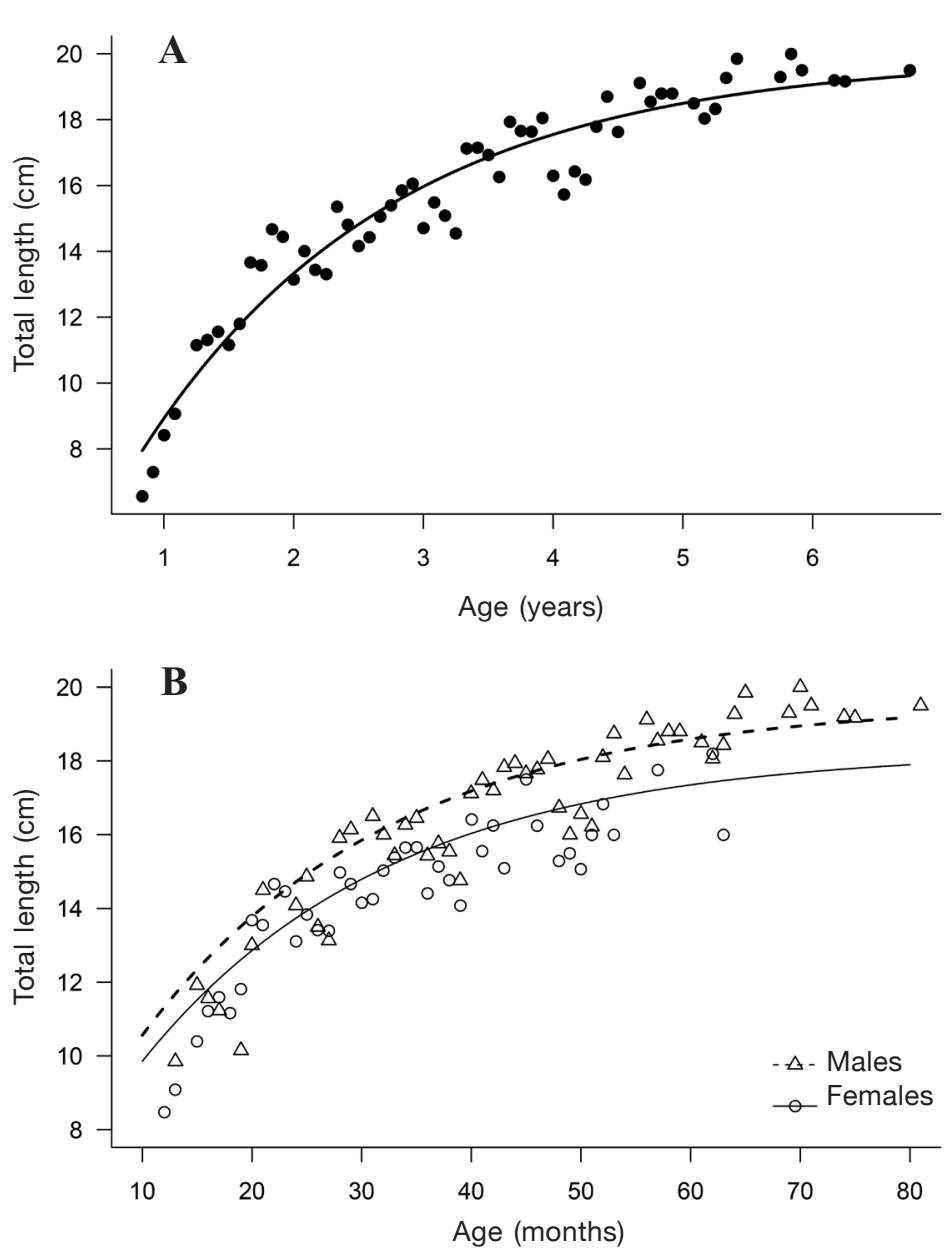

Figure 5

Von Bertalanffy growth function curves of picarel (Spicara smaris) collected during 1998-1999 in the Saronikos Gulf, Greece, based on ages determined from otoliths for (A) all fish (sex determined and sex undetermined) combined and (B) males and females separately.

first year of picarel life was essential to track completion of the $1^{\text {st }}$ annulus.

The periodicity of annulus formation, shown by monthly examination of MIs, showed that these increments were true annuli. It should be noted that different marks can be occasionally laid down on whole otoliths, which are not age related but are due to events such as settlement, spawning, or maturity (Campana, 2001). However, those marks do not show the normal periodicity and structure of annuli as happens with true annuli. In the present work, the date of annuli completion, based on the MIs study, was estimated to occur after June, when the percentage of otoliths with a hyaline area on the edge was the highest (see Suppl. Fig 3).

The time of estimated annuli formation coincides with the end of spawning and is in general agreement 


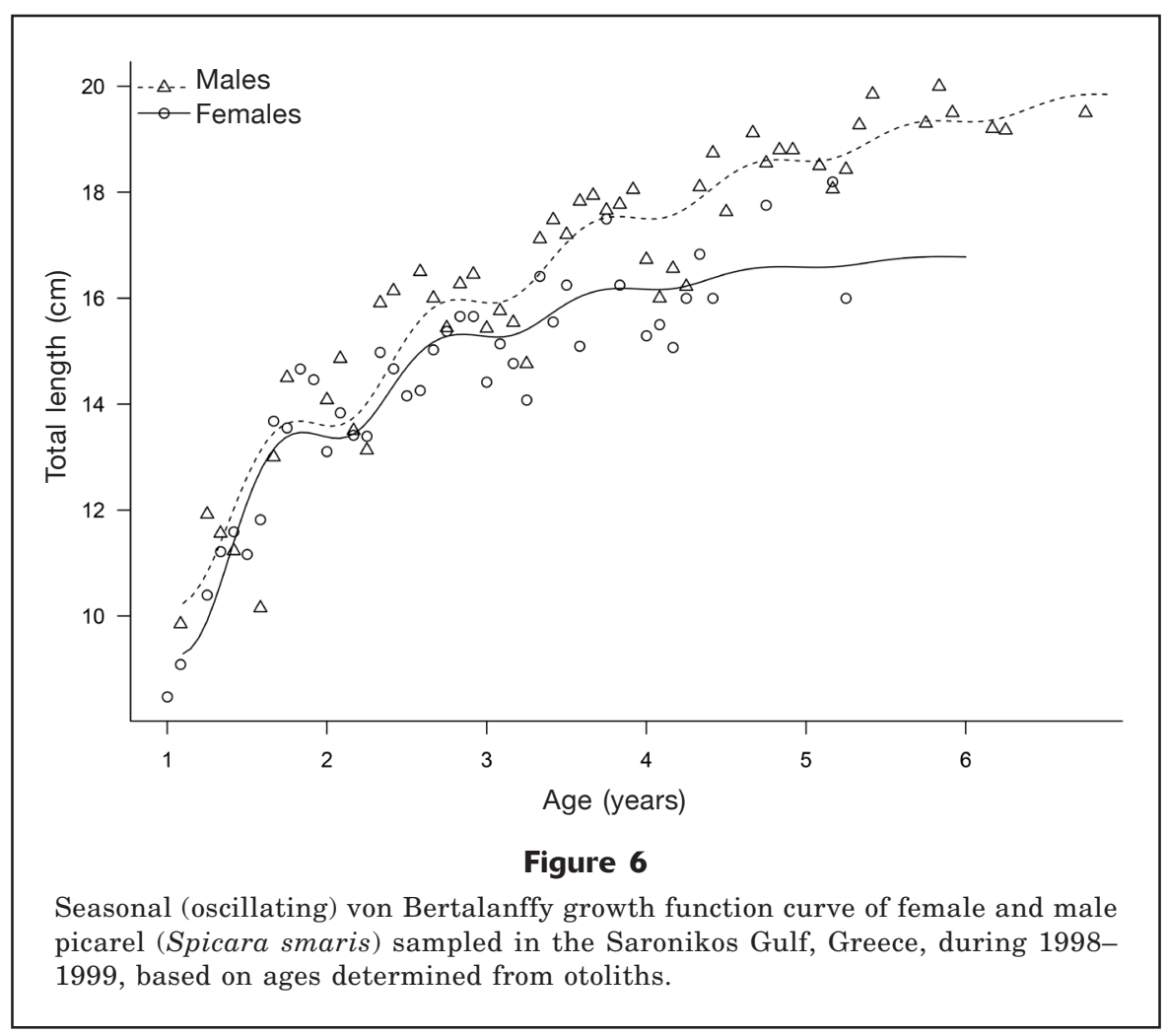

with the findings of Vidalis and Tsimenidis (1996), who also validated annulus completion by MI analysis. Denaxa et al. (2014), who determined picarel ages in Greek waters by means of otolith microstructure, reported that the first annulus is completed between January and April and formed between 180 (6 months) and 372 days (12.4 months) of life, which correspond to 8.63 and $14.3 \mathrm{~cm}$ TL respectively. The data of Denaxa et al. (2014) seem to be slightly lower than those of the present study, where the first annulus appears in otoliths from fish between 9.7 and $15.0 \mathrm{~cm}$ TL. Cluster analysis based on the similarity indices, and after we compared the length frequency distributions of fish classified according to their otolith readings, showed both the validity of the age interpretation criteria and an alternative way to assign the fish to age groups. It can be concluded that fish with similar lengths belong to the same age group, a relationship that many times in the past has been verified (Francis and Campana, 2004).

The application of the VBGF as a nonlinear approach to fitting length-at-age data is commonly used to describe fish growth, given that it is still the most useful tool for growth analysis despite the criticism of its use. As stated by Kimura (1980), rejection of the VBGF curve must ultimately be based on superior alternative curves or methods of analysis. In our work, we noticed good fitting (see Fig. 5), and the growth parameters were found to be very reasonable $\left(L_{\infty}\right.$ close enough to the $L_{\max }$ values observed, $t_{0}$ close enough to zero). The good fit of data in the present work is probably due to both a careful reading of annuli and the large number of specimens caught monthly. The mean observed lengths at ages $1,2,3$, and 4 for sexes combined as reported by Tsangridis and Filippousis (1992) are in general agreement with those of the present study. The smaller lengths at age estimated by the VBGF as reported by Ismen (1995), Vidalis and Tsimenidis (1996), and Dulčic et al. (2003), when compared to those of our study, are probably due to the interpretation of pre-annual (false) zone as the $1^{\text {st }}$ annulus. Slight differences in lengths at age were also found between those in the present work and those in the work by Rizkalla (1997). It is noted, however, that lengths in Rizkalla (1997) were estimated with the back calculation method. It is worth noting that in both works (Vidalis and Tsimenidis, 1996; Rizkalla, 1997), differences in the growth rate between sexes (males become longer than females) were not observed.

An oscillating pattern in the growth of picarel was mentioned by Tsangridis and Filippousis (1992). In particular, they attribute the slowing down of growth rate to either maturity or sex change. In more detail, they observed only two oscillations related to two growth periods: one linked to a very fast female growth period (up to $15.0 \mathrm{~cm} \mathrm{TL}$ ) and the second linked to a male slow period (up to $19.0 \mathrm{~cm}$ TL). In the present study, the decrease in the observed average length for each sex is noticed from summer to autumn during the $2^{\text {nd }}$, $3^{\text {rd }}$, and $4^{\text {th }}$ year of life and is most likely related to the 

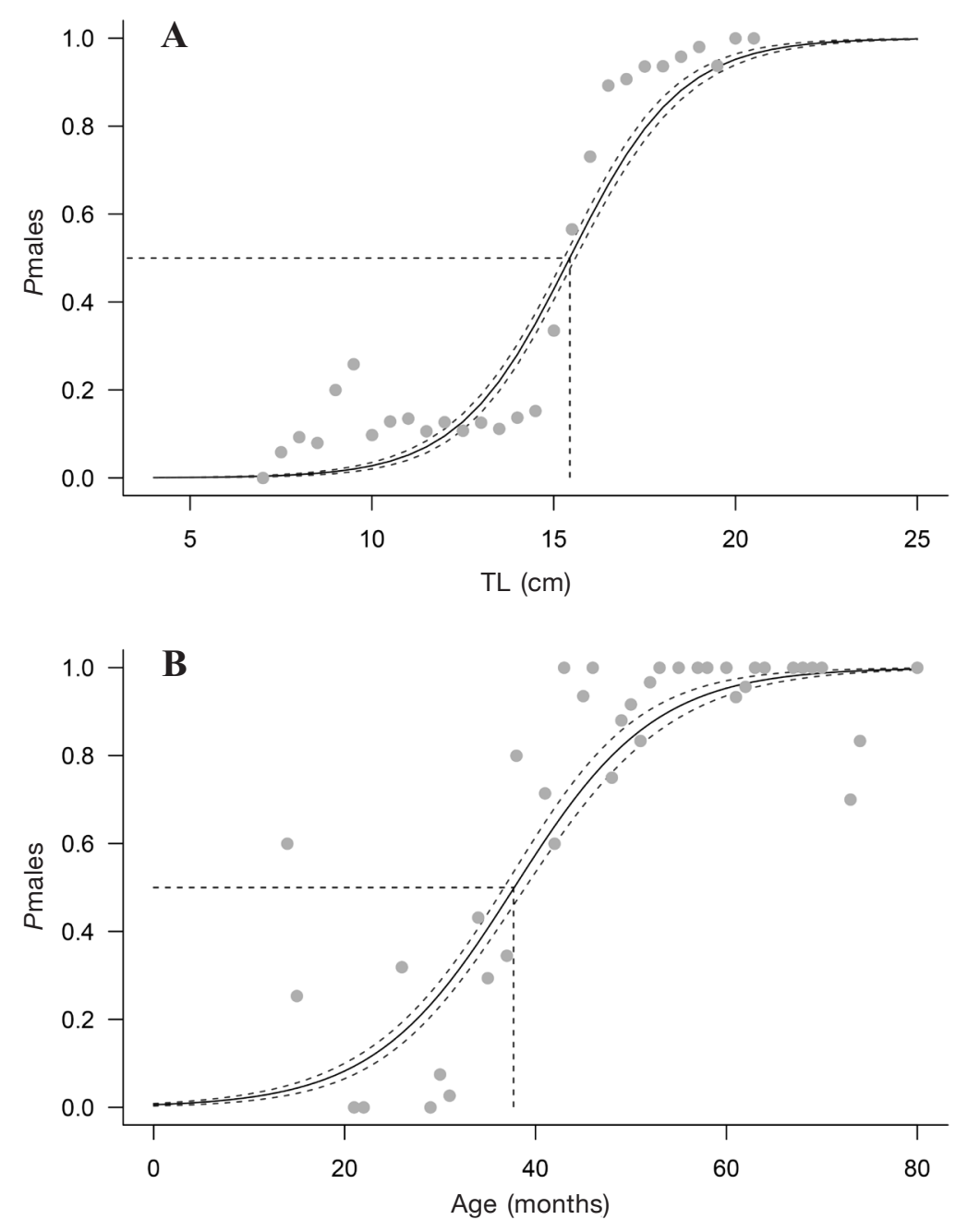

Figure 7

Fitted probability $(P)$ of picarel (Spicara smaris) being male with $(\mathbf{A})$ total length and (B) age and accompanying proportions of males per $0.5-\mathrm{cm}$ and 1-month classes, respectively. The length at median (50\%) female-to-male sex change was $15.34 \mathrm{~cm}$ in total length (TL). The age at median femaleto-male sex change was 36.4 months. The solid line indicates the fitted curve, the dotted lines indicate the $95 \%$ confidence intervals, and the gray circles indicate the observed data.

sex change. The presence of juveniles (see also Suppl. Fig. 1), as well as the high temperature $\left(19-25^{\circ} \mathrm{C}\right)$ which usually appears during this period (Suppl. Fig. 7), may play a role in the observed decrease in growth rate. It is noted however that Tsangridis and Filippousis (1994), who have tried a series of models for studying picarel growth, reported that the model that fitted best, showed that picarel growth changes when sex changes and the plotted curve also shows some kind of oscillation.

According to the literature (Salekhova, 1979; Tsangridis and Filippousis, 1992), sex change occurs after spawning, which is common in protogynous species
(Provost et al., 2017). In the present study, the majority of spent females were observed from June through September (see Suppl. Fig. 4). A change in sex during nonbreeding periods is not surprising because this strategy is predicted to maximize seasonal reproductive output in individual fish as mentioned by Provost et al. (2017). In an attempt to explain this decrease of average length, we believe that during sex transition, the longest females at each age (1, 2, and 3 years) change into males. Considering that the mean lengths at age of males are greater than those of females, this inversion results in lower mean lengths at age for each sex. The selection of larger females for inversion into males 
supports the size-advantage model (Warner, 1988). This model is particularly effective in accounting for postmaturational protogynous sex change among teleosts in which a few large males can monopolize mating within the population (Francis and Barlow, 1993; Erisman et al., 2009).

The $L_{50}(15.3 \mathrm{~cm}$ TL $)$ of this study, which corresponds to an age of 3 years $\left(A_{50}=3.0\right.$ years $)$, is in general agreement with previous reports (Salekhova, 1979; Tsangridis and Filippousis, 1992; Dulčiç et al., 2003). It is noted, however, that initial maturation was observed at about one-half year old, or about $10 \mathrm{~cm}$ TL (Suppl. Figs. 4 and 6). According to the dimensionless theory (Charnov and Skúladóttir, 2000), the ratio of $L_{50} / L_{\max }$ is invariant. Allsop and West (2003a), who found support for this theory across 52 fish species, estimated the relative ratio at 0.80 , a ratio that is related neither to the mating system nor to the presence of EMMs. When the same authors extended the list of species and estimated the same ratio for 77 species of fish, echinoderms, crustaceans, and molluscs, they found a value equal to 0.72 and concluded that the time when sex change occurs, is invariant for all animals (Allsop and West, 2003b). The same authors, on the other hand, agree that the invariant value of $L_{50} / L_{\max }$ corresponds to those species when the following criteria are met: 1) the species should be a unidirectional sex changer and 2) if it is diandrous, the proportion of EMMs should be low, $\leq 2 \%$ according to Allsop and West (2004b). In the case of picarel, the species is a unidirectional sex changer (the proportion of males is positively correlated with body length), whereas the proportion of EMMs, estimated at $2.4 \%$, which is close enough to $2 \%$, can be considered low. More specifically, Allsop and West (2004b) agree that the value of $2 \%$ EMMs is the upper limit for those species characterized as pure sex changers. The value of $L_{50} / L_{\max }$ estimated in this work (0.74), although is lower than the original estimated ratio $\left(L_{50} / L_{\max }=0.80\right)$, is close enough to the value of 0.72 of the extended list of Allsop and West (2003b) and within the $L_{50} / L_{\max }$ range (from 0.62 to 0.84 ) estimated by Allsop and West (2003a) for 4 (other than picarel) species of the Sparidae family. Thus, the dimensionless theory could be potentially supported and it can be concluded that the animals change sex at a certain proportion of their $L_{\max }$. A number of studies, on the other hand, have implicated fishing pressure as a cause of decline in the size at sex change (Platten et al., 2002; Hamilton et al., 2007) and therefore it should be noted that sequential hermaphrodites are more sensitive to size-selective harvesting than separate-sex species (Hamilton et al., 2007).

According to the sex allocation theory (Charnov et al., 1978), the population is compensating for decreases in reproductive capacity. Picarel exhibit male parental care, where the males guard the eggs in their nest until time of hatching (Harmelin and Harmelin-Vivien, 1976). It seems that the picarel represents a rare example of a species that exhibits co-occurring protogynous sex change and parental care. Although this feature of synchronicity could reduce the potential reproductive rate of males and hence the selection for sex change (i.e, the selection of females undergoing a sex change) (Allsop and West, 2004a), it seems that for picarel, as for some labrids (Warner and Lejeune, 1985), the cost of minimal parental care is outweighed by the benefit of larger male size in attracting and spawning with multiple females. On the other hand, the production of EMMs, which depends on the structure of the mating system, increases with high population density. High densities destabilize the potential for mate monopolization and therefore selection for sex change (Allsop and West, 2004a). Preliminary results of stock assessment in the area (Karlou-Riga and Anastopoulou, 2005) showed that the picarel stock is under or lightly exploited (ratio of current spawning stock biomass to virgin stock biomass is about $80 \%$ ). Therefore, high local population density is probably another potential factor, which could reduce the proportion of individuals undergoing a sex change and increase the proportion of EMMs. The findings of the present work most probably support the statement of Allsop and West (2004a), who suggested that the abundance of EMMs can be used as a measure of the amount of sex change taking place.

\section{Acknowledgments}

This work is a contribution to the "Management plans-Surveys in highly commercial fishing areas" Research Project, supported by the Hellenic Ministry of Rural Development and Food (Project Code 9686535). The authors wish to thank the staff of the Fisheries Laboratory of the Hellenic Ministry of Rural Development and Food, who collaborated on this project and in particular the three anonymous reviewers for critically reading the manuscript, providing insightful comments, and suggesting substantial improvements.

\section{Literature cited}

Allsop, D. J., and S. A. West.

2003a. Constant relative age and size at sex change for sequentially hermaphroditic fish. J. Evol. Biol. 16:921929. Article

2003b. Changing sex at the same relative body size. Nature 425:783-784. Article

2004a. Sex allocation in the sex-changing marine goby, $\mathrm{Co}$ ryphopterus personatus, on atoll-fringing reefs. Evol. Ecol. Res. 6:843-855.

2004b. Sex-ratio evolution in sex changing animals. Evolution 58:1019-1027. Article

Beamish, R. J., and G. A. McFarlane.

1983. The forgotten requirement for age validation in fisheries biology. Trans. Am. Fish. Soc. 112:735-743. Article

Bray, J. R., and J. T. Curtis.

1957. An ordination of the upland forest communities of southern Wisconsin. Ecol. Monogr. 27:325-349. Article 
Caddy, J. F.

1989a. A research strategy in support of stock evaluation of demersals in the Mediterranean Sea. In Report of the second technical consultation of the General Fisheries Council for the Mediterranean on stock assessment in the eastern Mediterranean; Athens, Greece, 28 March-1 April 1988. FAO Fish. Rep. 412 (M. Savini and J. F. Caddy, eds.), p. 116-127. FAO, Rome.

1989b. Comments on yield calculation presented at recent GFCM technical consultations on stock assessment. In Report of the second technical consultation of the General Fisheries Council for the Mediterranean on stock assessment in the eastern Mediterranean; Athens, Greece, 28 March-1 April 1988. FAO Fish. Rep. 412 (M. Savini and J. F. Caddy, eds.), p. 201-206. FAO, Rome.

Campana, S. E.

2001. Accuracy, precision and quality control in age determination, including a review of the use and abuse of age validation methods. J. Fish Biol. 59:197-242. Article

Carr, A.

1997. Primer user manual: Plymouth routines in multivariate ecological research, $42 \mathrm{p}$. Plymouth Marine Laboratory, Plymouth, UK.

Charnov, E. L., and U. Skúladóttir.

2000. Dimensionless invariants for the optimal size (age) of sex change. Evol. Ecol. Res. 2:1067-1071.

Charnov, E. L., D. W. Gotshall, and J. G. Robinson.

1978. Sex ratio: adaptive response to population fluctuation in pandalid shrimp. Science. 200:204-206. Article

Çiçek, E., and D. Avşar.

2010. Growth and mortality of Spicara smaris (Linnaeus, 1758) off Karatas Coast (Iskenderun Bay). Ecol. Life Sci. 5:126-134.

Clarke, K. R., and R. N. Gorley.

2001. PRIMER v5: user manual/tutorial, 91 p. PRIMERE, Plymouth, UK.

DeMartini, E. E., A. R. Everson, and R. S. Nichols.

2011. Estimates of body sizes at maturation and at sex change, and the spawning seasonality and sex ratio of the endemic Hawaiian grouper (Hyporthodus quernus, F. Epinephelidae). Fish. Bull. 109:123-134.

Denaxa, M., P. Bekas, D. Tziertzidis, and Ch. Mytilineou.

2014. Preliminary study of juvenile picarel, Spicara smaris (Linnaeus 1758), growth from otolith microstructure. In HydroMedit 2014: $1^{\text {st }}$ International Congress of Applied Ichthyology \& Aquatic Environment; Volos, Greece, 13-15 November, p. 271-275.

Dulčiç, J., M. Bauchot, B. Grbec, and P. Cetinić.

2000. Age, growth and mortality of blotched picarel Spicara maena L. (Pisces: Centracanthidae) in the eastern central Adriatic. Fish. Res. 48:69-78. Article

Dulčiç, J., A. Pallaoro, P. Cetinić, M. Kraljević, A. Soldo, and I. Jardas.

2003. Age, growth and mortality of picarel, Spicara smaris L. (Pisces: Centracanthidae), from the eastern Adriatic (Croatian coast). J. Appl. Ichthyol. 19:10-14. Article

Erisman, B. E., M. T. Craig, and P. A. Hastings.

2009. A phylogenetic test of the size-advantage model: evolutionary changes in mating behavior influence the loss of sex change in a fish lineage. Am. Nat. 174:E83-E99. Article

Francis, R. C., and G. W. Barlow.

1993. Social control of primary sex differentiation in the Midas cichlid. Proc. Natl. Acad. Sci. U.S.A. 90:1067310675. Article
Francis, R. I. C., and S. E. Campana.

2004. Inferring age from otolith measurements: a review and a new approach. Can. J. Fish. Aquat. Sci. 61:12691284. Article

Hamilton, S. L., J. E. Caselle, J. D. Standish, D. M. Schroeder, M. S. Love, J. A. Rosales-Casian, and O. Sosa-Nishizaki. 2007. Size-selective harvesting alters life histories of a temperate sex-changing fish. Ecol. Appl. 17:22682280. Article

Harmelin, J. G., and M. L. Harmelin-Vivien.

1976. Observations "in situ" des aires de ponte de Spicara smaris (L.) (Pisces, Perciformes, Centracanthidae) dans les eaux de Port-Cros. Trav. Sci. Parc Natl. Port-Cros $2: 115-120$.

ICSEAF (International Commission for the Southeast Atlantic Fisheries).

1986. Otolith interpretation guide: No. 2, Cape horse mackerel, 24 p. ICSEAF, Madrid, Spain.

Ismen, A.

1995. Growth, mortality and yield per recruit model of picarel (Spicara smaris L.) on the eastern Turkish Black Sea coast. Fish. Res. 22:299-308. Article

Karakulak, F. S., H. Erk, and B. Bilgin.

2006. Length-weight relationships for 47 coastal fish species from the northern Aegean Sea, Turkey. J. Appl. Ichthyol. 22:274-278. Article

Karlou-Riga, C.

2000. Otolith morphology and age and growth of Trachurus mediterraneus (Steindachner) in the eastern Mediterranean. Fish. Res. 46:69-82. Article

Karlou-Riga, C., and I. Anastopoulou.

2005. Stock assessment of picarel (Spicara smaris) exploited by trawlers and beach seiners in the Saronikos Gulf (GFCM-GSA 22). In Report of the seventh session of the General Fisheries Commission for the Mediterranean (GFCM) Sub-Committee for Stock Assessment (SCSA); Rome, Italy, 26-30 September, p. 5-6. General Fisheries Commission for the Mediterranean, Rome.

Karlou-Riga, C., A. Argirokastritis, and N. Vrantzas.

1997. Catch and effort of species caught by trawler and beach seiner in the Saronikos Gulf. In Proceedings of the $5^{\text {th }}$ Hellenic Symposium on Oceanography and Fisheries, vol. 2; Kavala, Greece, 15-18 April, p. 25-28. National Centre for Marine Research, Athens, Greece.

Kimura, D. K.

1980. Likelihood methods for the Von Bertanlaffy growth curve. Fish. Bull. 77:765-776.

Mitcheson, Y. S. D., and M. Liu.

2008. Functional hermaphroditism in teleosts. Fish Fish. 9:1-43. Article

Mytilineou, C., and C. Papaconstantinou.

1991. Age and growth of Spicara flexuosa (Rafinesque, 1810) (Pisces, Centracanthidae) in the Patraikos Gulf (Greece). Sci. Mar. 55:483-490.

Mytilineou, C., C. Y. Politou, C. Papaconstantinou, S. Kavadas, G. D'Onghia, and L. Sion.

2005. Deep-water fish fauna in the eastern Ionian Sea. Belg. J. Zool. 135:229-233.

Nikolsky, G. V.

1963. The ecology of fishes, 351 p. Academic Press, London.

Ogle, D. H.

2018. FSA: fisheries stock analysis. R package vers. 0.8.20. [Available from website.] 
Panfili, J., H. de Pontual, H. Troadec, and P. J. Wright (eds.). 2002. Manual of fish sclerochronology, 464 p. IfremerIRD coedition, Brest, France.

Papaconstantinou, C., A. Zenetos, V. Vassilopoulou, and G. Tserpes.

2007. State of Hellenic fisheries, 467 p. Hell. Cent. Mar. Res., Athens, Greece.

Platten, J. R., I. R. Tibbetts, and M. J. Sheaves.

2002. The influence of increased line-fishing mortality on the sex ratio and age of sex reversal of the venus tusk fish. J. Fish Biol. 60:301-318. Article

Provost, M. M., O. P. Jensen, and D. L. Berlinsky.

2017. Influence of size, age, and spawning season on sex change in black sea bass. Mar. Coast. Fish. 9:126-138. Article

$\mathrm{R}$ Core Team.

2017. R: a language and environment for statistical computing. R Foundation for Statistical Computing, Vienna, Austria. [Available from website, accessed October 2017.]

Ragonese, S., F. Fiorentino, G. Garofalo, M. Gristina, D. Levi, S. Gancitano, G.B. Giusto, P. Rizzo, and G. Sinacori.

2004. Distribution, abundance and biological features of picarel (Spicara flexuosa), Mediterranean (Trachurus mediterraneus) and Atlantic (T. trachurus) horse mackerel based on experimental bottom-trawl data (MEDITS, 1994-2002) in the Strait of Sicily. In Report of the MedSudMed expert consultation on small pelagic fishes: stock identification and oceanographic processes influencing their abundance and distribution; Salammbô, Tunisia, 1-3 October 2003. GCP/RER/010/ITA/MSM-TD-05. MedSudMed Tech. Doc. 5, p. 100-114. FAO MedSudMed, Mazara del Vallo, Italy.

Rizkalla, S. I.

1997. Age and growth studies of picarels (Spicara flexuosa and Spicara smaris) in the Egyptian Mediterranean waters. Oebalia 28:75-86.

Russell, B., D. Pollard, and K. E. Carpenter.

2015. Spicara smaris. The IUCN Red List of Threatened Species 2014. e.T170283A1308287. [Available from website.]

Salekhova, L. P.

1979. Picarels (Spicara spp.) in the Mediterranean Basin, 172 p. Kiev Academy of Science, Kiev, Ukraine.

Stergiou, K. I., D. K. Moutopoulos, and G. Krassas.

2004. Body size overlap in industrial and artisanal fisheries for five commercial fish species in the Mediterranean Sea. Sci. Mar. 68:179-188. Article

Stergiou, K. I., P. K. Karachle, A. C. Tsikliras, and E. Mamalakis.

2011. Shouting fishes: fishes from the Greek seas-biology, fisheries and management, 358 p. Patakis Publishers, Athens, Greece. [In Greek.]
Tsangridis, A., and N. Filippousis.

1989. Length-based approach to the estimation of growth and mortality parameters of Spicara smaris (L.) in the Saronikos Gulf, Greece and remarks on the application of the Beverton and Holt relative yield per recruit model. In Report of the second Technical Consultation of the General Fisheries Council for the Mediterranean on stock assessment in the eastern Mediterranean; Athens, Greece, 28 March-1 April 1988. FAO Fish. Rep. 412 (M. Savini, M., and J. F. Caddy, eds.), p. 94-107. FAO, Rome.

1991. Use of length-frequency data in the estimation of growth parameters of three Mediterranean fish species: bogue (Boops boops L.), picarel (Spicara smaris L.) and horse mackerel (Trachurus trachurus L.). Fish. Res. 12:283-297. Article

1992. Growth pattern of picarel, Spicara smaris (L.) (Centracanthidae), a protogynous species. Cybium 16:233243.

1994. Analysis of two models for picarel (Spicara smaris L.) growth using Schnute's micro-simplex nonlinear estimation procedure. Fish. Res. 20:181-189. Article

Tsasitis, I., and C. Charilaou.

2016. Stock assessment form: Spicara smaris. General Fisheries Commission for the Mediterranean, Rome. [Available from website.]

Valle, C., J. T., Bayle, and A. A. Ramos.

2003. Weight-length relationships for selected fish species of the western Mediterranean Sea. J. Appl. Ichthyol. 19:261-262. Article

Vidalis, K., and N. Tsimenidis.

1996. Age determination and growth of picarel (Spicara smaris) from the Cretan continental shelf (Greece). Fish. Res. 28:395-421. Article

Vidalis, K., G. Markakis, and N. Tsimenides.

1997. Discrimination between populations of picarel (Spicara smaris L., 1758) in the Aegean Sea, using multivariate analysis of phenetic characters. Fish. Res. 30:191197. Article

Warner, R. R.

1988. Sex change and the size-advantage model. Trends Ecol. Evol. 3:133-136. Article

Warner, R. R., and P. Lejeune.

1985. Sex change limited by paternal care: a test using four Mediterranean labrid fishes, genus Symphodus. Mar. Biol. 87:89-99. Article

Whitehead, P. J. P., M.-L. Bauchot, J.-C. Hureau, J. Nielsen, and E. Tortonese.

1986. Fishes of the north-eastern Atlantic and the Mediterranean, vol. 1, 510 p. UNESCO, Paris.

Zei, M.

1950. Typical sex-reversal in teleosts. Proc. Zool. Soc. Lond. 119:917-920. Article 